\title{
Southern Benguela frontal region. I. Hydrology, phytoplankton and bacterioplankton
}

\author{
F. Verheye-Dua, M. I. Lucas \\ Marine Biology Research Institute, University of Cape Town, Rondebosch 7700, Cape Town, South Africa
}

\begin{abstract}
Physical and biological features of the shelf-break oceanic front of the southern Benguela upwelling region off the Cape Peninsula, South Africa, were studied in March 1983. The convergence front was situated between 90 and $110 \mathrm{~km}$ offshore, delineated by strong temperature and salinity gradients. Further inshore ( $45 \mathrm{~km}$ offshore), salinity sections revealed a shallow frontal feature between water masses of different upwelling origin. Recently upwelled water close inshore was slightly aged as indicated by some sun-warming to ca $15^{\circ} \mathrm{C}$, the development of high chlorophyll a (up to $9 \mathrm{mg} \mathrm{m}^{-3}$ ) and reduced nitrate concentrations $\left(<11 \mu \mathrm{g}\right.$-at $\left.\mathrm{N}^{-1}\right)$. These frontal regions were associated with elevated chlorophyll a concentrations and bacterial numbers. Although recently upwelled water was characterised by high chlorophyll a concentrations $\left(5\right.$ to $\left.8 \mathrm{mg} \mathrm{m}^{-3}\right)$, bacterial biomass was relatively low $(<20 \mathrm{mg}$ $\mathrm{C} \mathrm{m}^{-3}$ ) while the converse was generally true for older offshore waters $\left(<2 \mathrm{mg} \mathrm{chl} \mathrm{a} \mathrm{m}{ }^{-3} ; 20\right.$ to $40 \mathrm{mg}$ bacterial $\mathrm{C} \mathrm{m}^{-3}$ ). The overall positive relationship between chlorophyll a concentration and bacterial biomass was best described by a power curve as at high chlorophyll concentrations, bacterial biomass was proportionally reduced, probably due to predation. Close to the sediment water interface there was some evidence of nitrification. Indirect estimates of $\mathrm{NH}_{4}^{+}-\mathrm{N}$ regeneration by the microplankton $(<200$ $\mu \mathrm{m})$, based on bacterial biomass, suggested that physical mixing processes at the shelf-break front ensure that 'new' nitrogen $\left(\mathrm{NO}_{3}^{-}-\mathrm{N}\right)$ can be entrained into the euphotic zone, while well-stratified oceanic waters rely mainly $(65 \%)$ on regenerated nitrogen.
\end{abstract}

\section{INTRODUCTION}

Water column structure adjacent to the Cape Peninsula of South Africa is regulated in summer by intense but episodic upwelling conditions in response to strong seasonal southeasterly winds. The resulting upwelling plumes of cold nutrient-rich South Atlantic Central Water are characterised by consistent temperature and salinity (ca $10^{\circ} \mathrm{C}$ and $34.80 \%$; Andrews \& Hutchings 1980, Barlow 1982, Waldron 1985, Brundrit 1986). Transported offshore in a northwesterly direction, they eventually mix with or sink below the warm, high salinity oceanic water (ca $20^{\circ} \mathrm{C}$ and $35.5 \%$ ) at a convergence front (Hutchings et al. 1985, Armstrong et al. 1987). Variability in the surface features and position of the front are complex and are determined principally by the effects of changes in wind stress and sun warming. However, the chemical nature of upwelled South Atlantic Central Water, and of the front itself, may be modified substantially by biological activity (Hutchings et al. 1985, Armstrong et al. 1987).

Tidal 'fronts' or 'convergences', characteristic of European shelf waters, have been extensively studied with particular emphasis on phytoplankton productivity. Similar studies have also been carried out in coastal and offshore waters of the Califomian upwelling system (for review see Le Fèvre 1986). Most of these studies conclude that fronts are regions of increased biological activity with high phytoplankton standing stocks and enhanced primary production. However, passive accumulation of particulate material due to surface convergence has not been ruled out (Le Fèvre 1986)

During recent years, the role and importance of microheterotrophs in the plankton have been considered extensively where heterotrophic bacterial activity is closely associated with primary production (e.g. Linley et al. 1983, Bird \& Kalff 1984, Lancelot \& Billen 1984). In the southern Benguela upwelling region, at least $50 \%$ of the fixed carbon is estimated to pass through the microbial decomposer food chain (Lucas et al. 1986, Newell \& Turley 1987).

Several studies have also stressed the importance of microprotozoan predation in the control of bacterial numbers (e.g. Andersen \& Fenchel 1985, Sherr et al. 1986). This also has important implications for the role 
of bacteria and microflagellates in nitrogen cycling. Recent studies in the southern Benguela upwelling region have shown that organisms within the nanoplankton $(<15 \mu \mathrm{m})$ accounted for $95 \%$ of the total microplankton $(<200 \mu \mathrm{m})$ regeneration, with the picoplankton $(<1 \mu \mathrm{m})$, presumably bacteria, being more important in deeper waters (Probyn 1987).

This paper seeks to evaluate the importance of bacteria at the oceanic shelf-break front in the southern Benguela upwelling region with an emphasis on their distribution and density relative to phytoplankton biomass and the physical processes that control mixing and nutrient cycling at this boundary system. We also make some assessment of the significance of microbial activity to nitrogen cycling and phytoplankton productivity in this region.

\section{MATERIALS AND METHODS}

Sampling site. On 21 March 1983 hydrological, chemical and biological data were collected at 10 stations along the Upwelling Monitoring Line (UML), situated off the west coast of the Cape Peninsula, South Africa (Fig. 1). This line of stations $(5.5,13.5,21.5,33.0$, $42.0,52.0,61.0,80.0,98.0$ and $114.5 \mathrm{~km}$ from the coast), traversed the southern Benguela oceanic front at 90 to $110 \mathrm{~km}$ offshore.

Physical and chemical. At each station, conductivity, temperature and density (CTD) profiles were recorded down to the bottom (up to $433 \mathrm{~m}$ depth). Water samples were obtained using a rosette sampler triggered at 12 irregular depths determined by $100 \%, 50 \%, 25 \%$ and $1 \%$ irradiance depths and the position of the pycnocline. Subsamples (ca $25 \mathrm{ml}$ ) were pre-filtered through $25 \mathrm{~mm}$ Whatman GF/F filters and the filtrate frozen prior to nitrate analysis in the laboratory on a Technjcon Autoanalyser (AAII) according to the methods described by Mostert (1983). Oxygen concentrations were determined on board ship using standard Winkler techniques.

Bacterial numbers and biomass. Total bacterial counts were determined from $10 \mathrm{ml}$ water samples, fixed with $1.0 \mathrm{ml}$ Analar Gluteraldehyde $(2.5 \%$ final concentration) and stored in the dark at $5^{\circ} \mathrm{C}$ prior to counting. Samples were prepared and stained according to the Acridine Orange Direct Counting method (AODC) of Hobbie et al. (1977). At least 20 microscopic fields or about 300 bacteria were counted per sample. Distinction was made between 5 bacterial groups distinguished by size and morphology (Fig. 4 ; Painting et al. 1985). Bacterial biomass was calculated from biovolume estimates of the cells, using a specific gravity value of $1.1 \mathrm{~g} \mathrm{~cm}^{-3}$ for bacterial cells (Linley et al. 1983). Contrary to proposals of Bratbak (1985) and

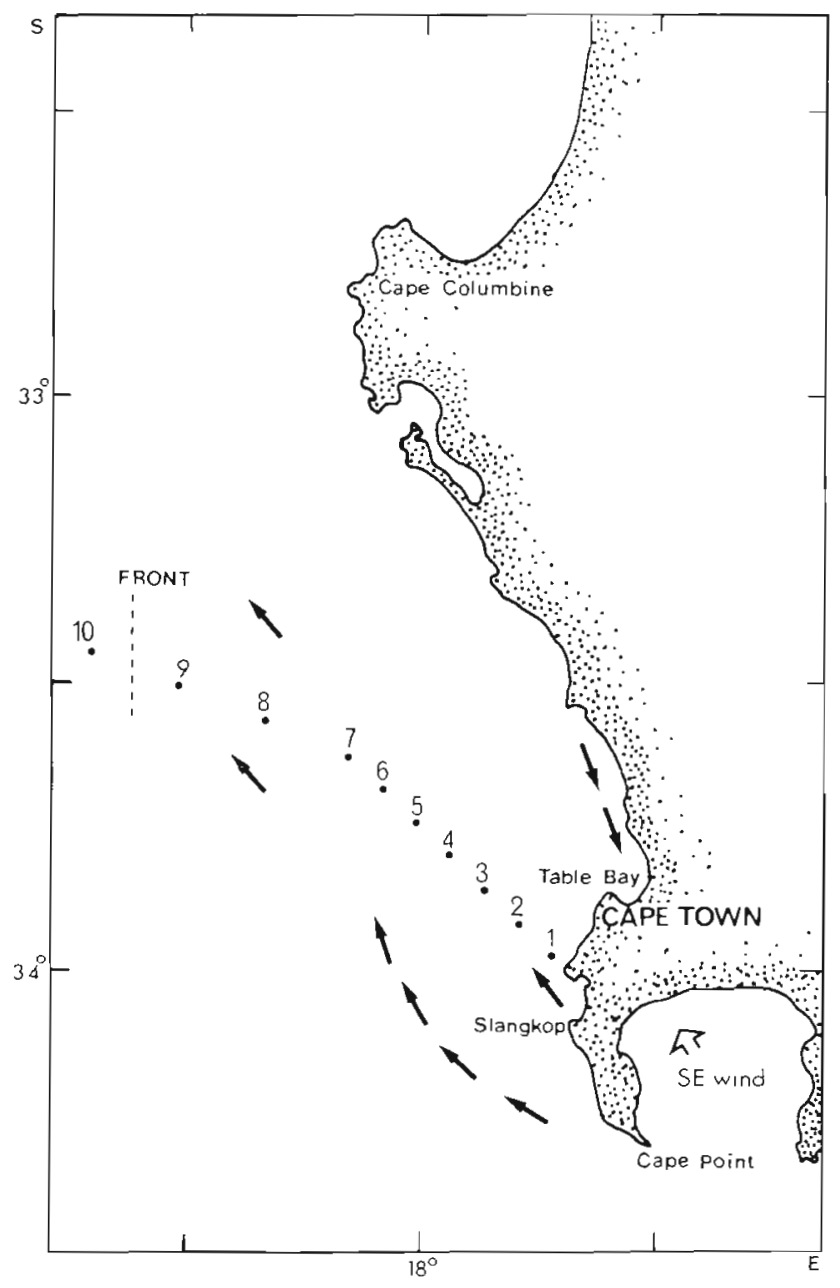

Fig. 1. Sampling line off the Cape Peninsula, South Africa. Arrows indicate current patterns

Bjørnsen (1986), we retained the commonly used factor of 0.11 for the conversion of wet bacterial biomass to carbon, since their high estimates of cellular carbon are based either on cultured or on estuarine bacteria.

Phytoplankton standing stocks. Up to $2.0 \mathrm{l}$ of seawater were filtered through $47 \mathrm{~mm}$ Whatman GF/F filters for each depth and stored frozen prior to analysis for chlorophyll a. As an index of phytoplankton standing stock, chlorophyll a was measured in accordance with the trichromatic equations of the SCOR/UNESCO Working Group 17 (1966).

\section{RESULTS AND DISCUSSION}

\section{Wind stress}

The progressive wind vector data given by Hutchings et al. (1984) show that moderate to strong southeasterly winds persisted almost continually during the 
period 8 February to 31 March 1983. As these wind regimes were of sufficient velocity (i.e. more than $5 \mathrm{~m}$ $\mathrm{s}^{-1}$ ), upwelling conditions were generated which can approach a maximum of $32 \mathrm{~m} \mathrm{~d}^{-1}$ (Andrews \& Hutchings 1980). However, prior to sampling the UML on 21 March, a wind reversal to the NW occurred on 19 March, associated with the passage of a cold front. This resulted in a relaxation of the upwelling conditions and, indeed, the intensity of upwelling during the 1982-1983 summer was about a third reduced relative to normal summer conditions (Hutchings et al. 1984). The results of this wind reversal were apparent in the CTD sections for Stns 1 to 10 along the UML (Fig. 2) and are discussed below.

\section{Hydrological features of the front}

Temperature and salinity sections for surface waters (down to $80 \mathrm{~m}$ ) of the UML on 21 March 1983 are shown in Fig. 2a, b. The overall picture reveals a welldefined oceanic front in the region of the shelf-break, characterised by strongly downturned isotherms and isohalines. As seawater density in this region is governed by temperature rather than salinity, isopycnals will conform to the temperature section.

A shallow $(<15 \mathrm{~m}$ ) upper mixed layer extending from $10 \mathrm{~km}$ offshore to the shelf-break front was characterized by 14 to $15^{\circ} \mathrm{C}$ sun-warmed water. Despite prevailing NW winds on 21 March, this warm surface layer was not an intrusion of warm oceanic water $\left(15\right.$ to $19^{\circ} \mathrm{C}$ ), since the conservative properties of salinity (Waldron 1985, Brundrit 1986) were those of older matured upwelled water ( 34.78 to $34.90 \%$ ) rather than of oceanic water (> $35.0 \%$ ) (Andrews \& Hutchings 1980, Barlow 1982, Waldron 1985). At Stn 10, the surface water appeared to be a wind-mixed, sunwarmed extension of the subsurface water. It is clear that upwelling, in the sense of subsurface water entering the surface layer, only took place at the innermost station. The salinity section also reveals another front in the inshore surface waters $(0$ to $20 \mathrm{~m})$ at ca 40 to $50 \mathrm{~km}$ offshore, characterised by the interleaving of 2 adjacent but distinct water masses. Another prominent feature of the salinity section is the apparent 'budding-off' of oceanic water across the shelf-break front to the nearshore side. The mean flows parallel to the front are rarely in ideal geostrophic balance with density gradients and discontinuity in the density distribution results in cross-frontal velocity shear. These baroclinic instabilities cause the frontal structure to evolve into a baroclinic eddy (Fig. 2b). Frontal eddies are a common feature of the shelf-break front and have been observed regularly on satellite images of the southern Benguela upwelling region (Shannon et al. 1985). They

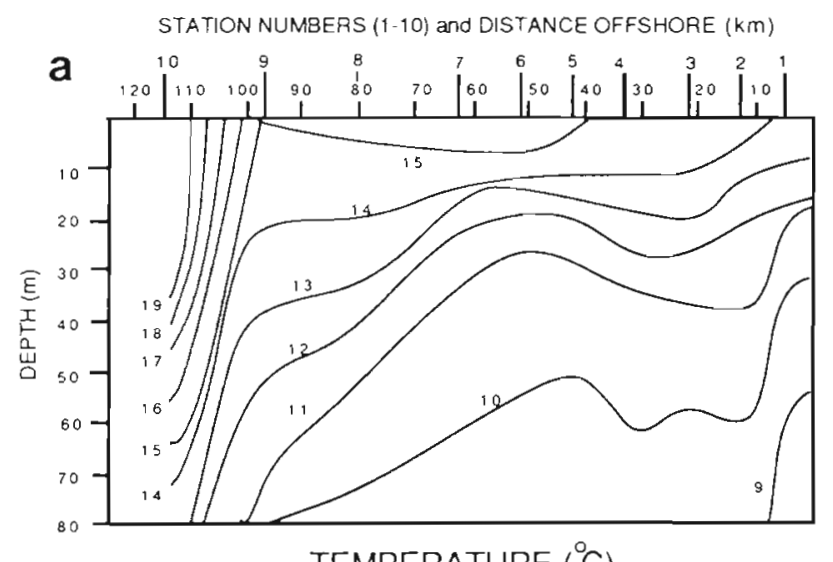

TEMPERATURE $\left({ }^{\circ} \mathrm{C}\right)$
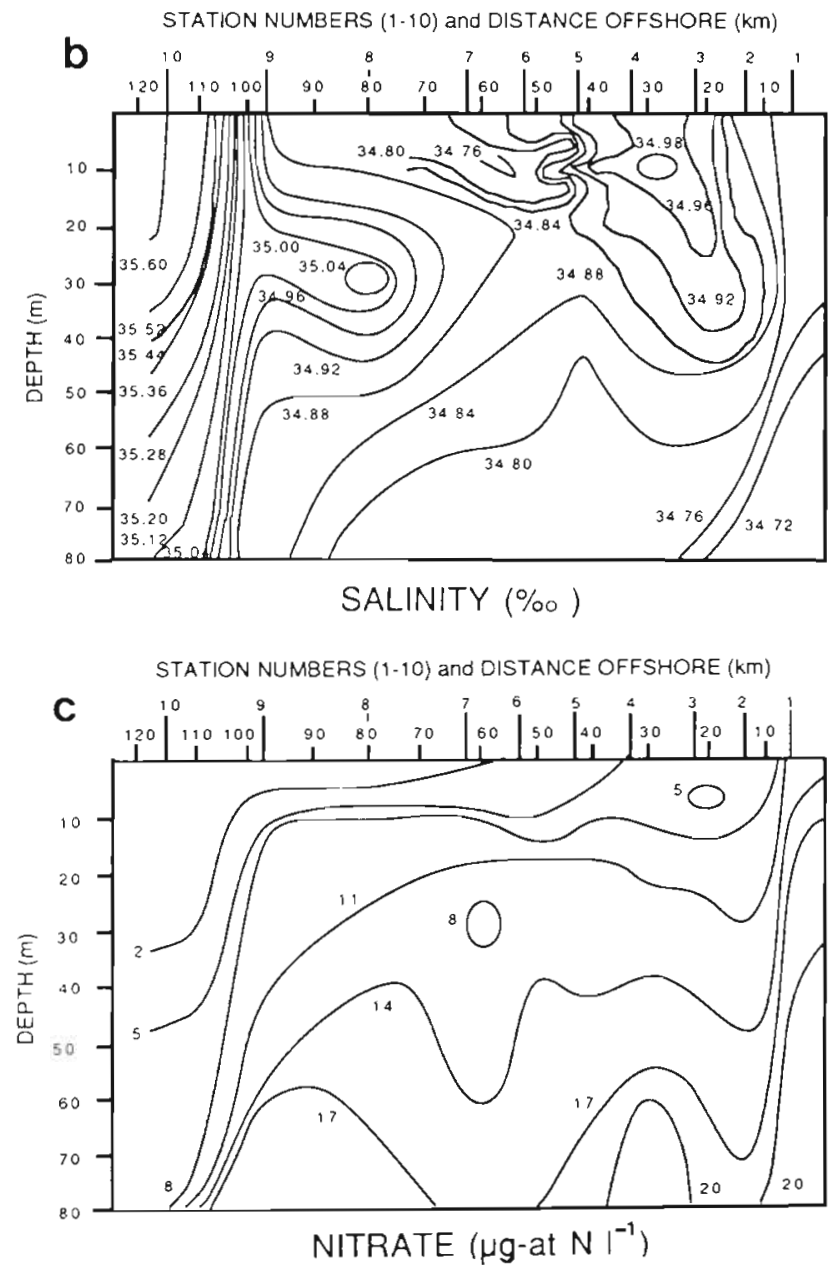

Fig. 2. Vertical sections of (a) temperature $\left({ }^{\circ} \mathrm{C}\right)$, (b) salinity $(\%)$ and $(\mathrm{c})$ nitrate $\left(\mu \mathrm{g}\right.$-at. $\left.\mathrm{l}^{-1}\right)$ along the upwelling monitoring line (UML)

are characterised by a high potential for cross-frontal mixing of nutrients (for review see Le Fèvre 1986). Similarly, the interleaving apparent at ca $45 \mathrm{~km}$ off- 
shore may also produce cross-frontal shear. Although both these water masses apparently have similar nitrate concentrations of 2 to $8 \mu \mathrm{g}$-at $\mathrm{N}^{-1}$ ), they may be complementary with respect to other limiting nutrients. For the southern Benguela upwelling region, Nelson (1985) described typical north-flowing current speeds of the order of 20 to $30 \mathrm{~cm} \mathrm{~s}^{-1}$. However, particularly after wind reversals and during the relaxation period, there is a pronounced nearshore net southward flow from Cape Columbine to Slangkop over a width of 20 to $30 \mathrm{~km}$ which can reach similar current velocities. Interpretation of Fig. $2 \mathrm{~b}$ leads, therefore, to the conclusion that the upwelled water mass between 20 and $40 \mathrm{~km}$ offshore originated from the north (Table Bay region) while the water mass between 40 and $70 \mathrm{~km}$ offshore originated from the south (Slangkop region).

\section{Nitrate}

Steeply rising nitriclines ( 14 to $20 \mu \mathrm{g}$-at $\mathrm{N}^{-1}$ ) adjacent to the coast (Fig. 2c) provide evidence of recent upwelling. With increasing distance from the shore nitrate decreased slowly as a consequence of phytoplankton development in stratified surface waters (Fig. 3b). Nitrate concentrations of the inshore southward-flowing surface waters ( 5 to $8 \mu \mathrm{g}$-at $\mathrm{Nl}^{-1}$ ) and the adjacent northward-flowing water mass ( 2 to $5 \mu$ g-at $N$ $\left.1^{-1}\right)$ were both non-limiting. Steeply inclined nitriclines at the oceanic front revealed the paucity of nitrate on the oceanic side (max. $1.7 \mu \mathrm{g}$-at $\mathrm{N} \mathrm{I}^{-1}$ at $30 \mathrm{~m}$ depth) while on the inner side, a reservoir of nitrate was apparent at $10 \mathrm{~m}$ depth. Physical mixing processes associated with upwelling or frontal turbulence and the proximity of the nitrate reservoir are always likely to ensure a supply of 'new' nitrogen $\left(\mathrm{NO}_{3}^{-}-\mathrm{N}\right)$ to surface waters over the shelf region. The stability and stratified nature of the oceanic region, on the other hand, will limit the injection of 'new' nitrogen into surface waters, creating a dependence on 'regenerated' nitrogen, mediated by biological processes. Size-fractionated studies on nitrogen uptake and regeneration by Probyn $(1985,1987)$ and Probyn \& Lucas (1987) in the southern Benguela region confirm this.

A classification of different water-types in the southern Benguela region on the basis of temperature, salinity and nutrient concentration has been compiled by Andrews \& Hutchings (1980), Barlow (1982) and Bailey \& Chapman (1985). Surface waters at the time of sampling fell into the 'maturing upwelled water' (10 to $15^{\circ} \mathrm{C}, 2$ to $15 \mu \mathrm{g}$-at $\mathrm{NO}_{3}^{-}-\mathrm{N} \mathrm{l}^{-1}$; Type 2) and 'aged upwelled water' $\left(12\right.$ to $16^{\circ} \mathrm{C}, 0$ to $2 \mu \mathrm{g}$-at $\mathrm{NO}_{3}^{-}-\mathrm{N} \mathrm{l}^{-1}$; Type 3) categories, consistent with the salinity and wind stress features associated with relaxation of upwelling noted earlier.
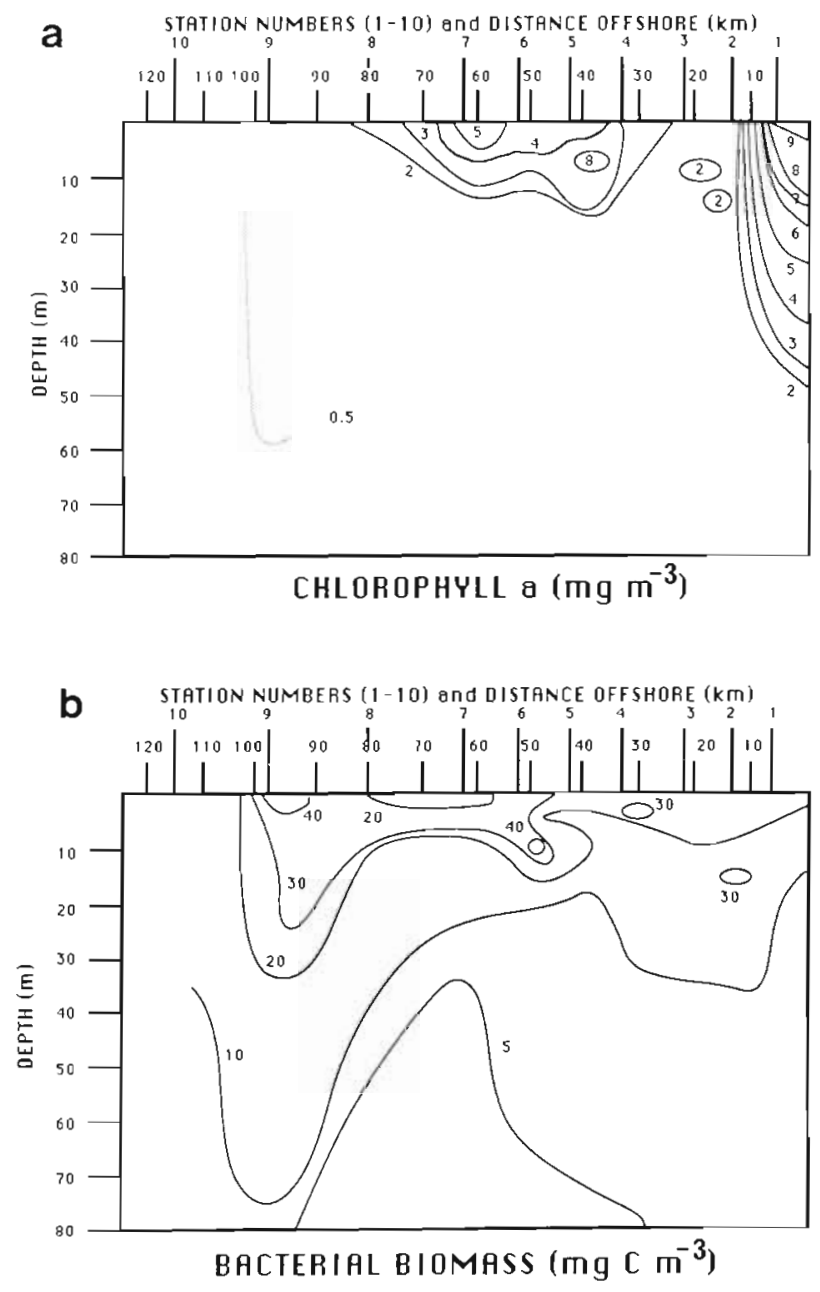

Fig. 3. Vertical sections of (a) chlorophyll a $\left(\mathrm{mg} \mathrm{m}^{-3}\right)$ and (b) bacterial biomass ( $\mathrm{mg} \mathrm{C} \mathrm{m}^{-3}$ )

\section{Phytoplankton and bacterioplankton}

Sections of phytoplankton biomass and associated bacterial biomass for the UML in March 1983 are shown in Fig. 3a, b. As expected, the highest phytoplankton biomass (9.8 $\mathrm{mg} \mathrm{chl} \mathrm{a} \mathrm{m}^{-3}$, Fig. 3a) was associated with recently upwelled water (Type 2 ; Barlow 1982). Here, nitrate concentrations were high (> 8 $\mu$ g-at ${\mathrm{N} 1^{-1}}^{-1}$ Fig. 2c) and diatoms dominated, as described by Hutchings et al. (1984). Although bacterial populations may develop rapidly $(<2$ d) in response to phytoplankton growth in upwelled waters (Lucas et al. 1987), bacterial biomass at Stn 1 (Fig. 3b) was low, indicating the very recent development of the bloom. The northwesterly wind at the time of the sampling maintained the phytoplankton bloom within $10 \mathrm{~km}$ of the coast. Further offshore (10 to $20 \mathrm{~km}$ ) surface chlorophyll a concentrations dropped markedly to $<1.0 \mathrm{mg} \mathrm{m}^{-3}$, while bacterial biomass remained 
high, particularly in the oldest water furthest offshore (Type 3; Barlow 1982). An exception to this trend was seen at the secondary inshore front (45 km offshore) where phytoplankton and bacterioplankton biomasses

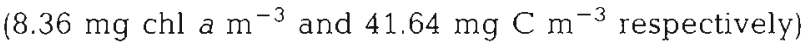
were stimulated by shear turbulence, associated with 2 opposite-flowing water masses as described earlier. The high bacterial biomass at the oceanic front (max $49.93 \mathrm{mg} \mathrm{C} \mathrm{m}^{-3}$ ) was on the other hand not associated with high chlorophyll a concentrations (max. $0.14 \mathrm{mg}$ $\mathrm{m}^{-3}$ ) but may reflect the historic presence of higher chlorophyll a concentrations or other particulate accumulations at the front.

Bacterial cell counts along the whole UML remained relatively constant at about $10^{5}$ to $10^{6}$ cells $\mathrm{ml}^{-1}$, which is in agreement with cell records for other productive coastal, euphotic offshore and oceanic waters. However, no depth-related changes in dominating bacterial type were observed as have been reported by other workers (e.g. Linley et al. 1983). Fig. 4 clearly shows that small cocci (volume $=0.009 \mu^{3}$ ) and large cocci (volume $=0.142 \mu^{3}$ ) numerically dominated the bacterioplankton (ca $60 \%$ and $20 \%$ respectively at all depths). Bacterial biomass was nevertheless dominated by large cocci (volume $=0.142 \mu \mathrm{m}^{3}$ ) and rods (volume $=0.198 \mathrm{\mu m}^{3}$ ) which formed approximately $53 \%$ and $27 \%$ of the total bacterial biomass. There appeared to be no significant difference in the integrated numerical or biomass composition of the bacterioplankton between any of the stations (Fig. 4).

The close coupling of bacterial activity to phytoplankton production is now well known. Several workers have attempted to show this relationship empirically by correlating bacterial abundance or biomass with chlorophyll a concentrations (e.g. Linley et. al. 1983, Bird \& Kalff 1984, Painting et al. 1985). Although bacteria and phytoplankton are tightly linked, there remains some considerable unexplained scatter and the confidence limits for an individual prediction are wide (Table 1). Pooled data for chlorophyli a concentrations and bacterial biomass along the UML were poorly correlated. However, bacteria-chlorophyll a relations became quite clearly resolved by splitting the data into 4 groups, based largely on the age of the water (Table 1a; Fig. 5). Thus, in young, newly upwelled water masses or in active frontal systems (Stns 1 and 5), phytoplankton growth is stimulated by nutrient availability and herbivory may be of little significance, so allowing an increase in chlorophyll concentrations. In these waters, bacterial biomass: chlorophyll a ratios were low (i.e. high chlorophyll a concentrations). In older water types (Stns 2, 3, 4, 6, 7, 8) phytoplankton may be limited by nutrient availability, light or both and subject also to greater grazing pressure. Here bacterial biomass:chlorophyll a ratios were higher. On a BACTERIAL NUMBERS

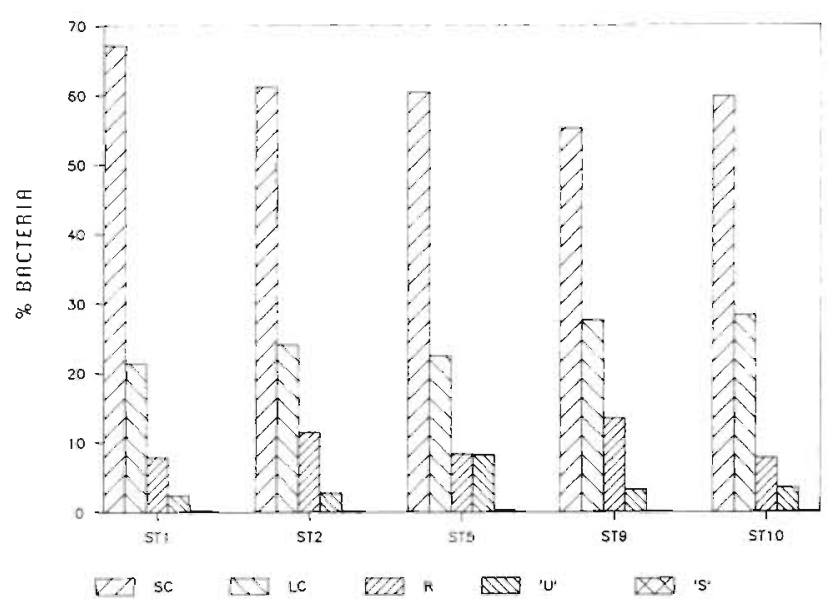

b

BACTERIAL BIOMASS

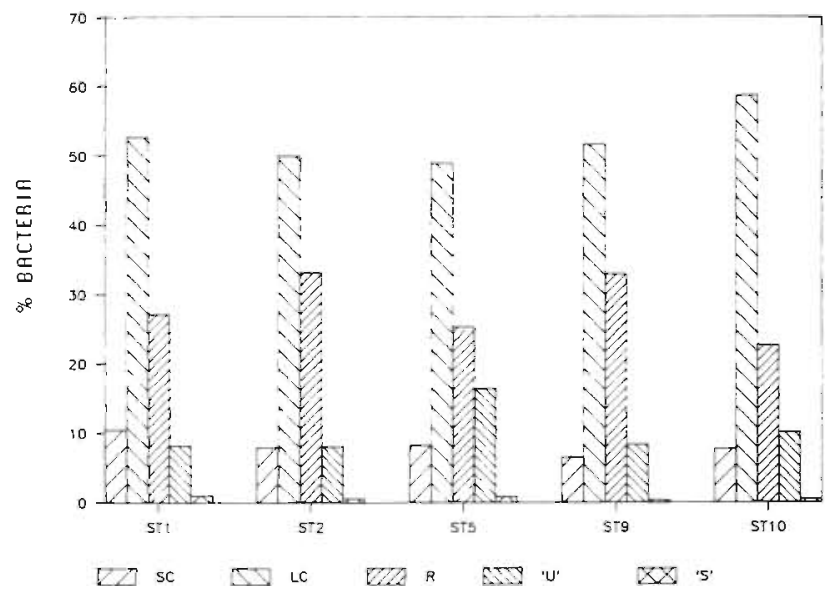

Fig. 4. Histograms showing percent of (a) numbers and (b) biomass of the different bacteria at 5 selected stations. SC: small cocci; LC: large cocci; R: rods; U: U-shaped bacteria; 'S'. S-shaped bacteria

the other hand, senescent phytoplankton blooms stimulate bacterial populations which may exceed the carbon biomass of phytoplankton as occurred at the inner edge of the shelf-break front and in the oceanic waters. These waters were characterised by high bacterial biomass : chlorophyll a ratios (i.e. low chlorophyll a concentrations) (Table 1 ; Fig. 5). These relations confirm Barlow's observations (1982) that older (Type 2 and 3) water may be dominated by bacteria and detritus whilst young (Type 1) waters will be dominated by active phytoplankton with high chlorophyll a concentrations. Well-ordered successions of phytoplankton, bacteria and protozoans seem characteristic of planktonic community development in upwelling waters as Lucas et al. (1987) demonstrated in a microcosm which simulated an upwelling event. It is clear that the age of the water is important in determining 
Table 1. Regression equations relating bacterial biomass or abundance to chlorophyll a concentrations. (A) Present data; linear relations between bacterial biomass and chlorophyll $a: Y=a+b . X$ where $X=\mathrm{chl}^{\mathrm{a}} \mathrm{in} \mathrm{mg} \mathrm{m}^{-3}, \mathrm{Y}=\mathrm{bacterial}$ biomass in $\mathrm{mg} \mathrm{C}$ $\mathrm{m}^{-3}$. (B) Literature and present data; linear relations between bacterial abundance and chlorophyll $a$ : $Y=a+b . X$, where $X=c h l$ a in $\mathrm{mg} \mathrm{m}^{-3}, y=$ bacterial numbers in $10^{5}$ (C) Literature and present data: logarithmic relations between bacterial abundance and chlorophyll a: $\log Y=\mathrm{a}+\mathrm{b} \log X$, where $X=\mathrm{chl} a$ in $\mathrm{mg} \mathrm{m}^{-3}, Y=$ bacterial numbers in $10^{5}$

\begin{tabular}{|c|c|c|c|c|c|}
\hline Location & Regression equation & $n$ & $r$ & $p$ & Source \\
\hline (A) Stns 1 and 5 & $Y=6.49+1.41 X$ & 22 & 0.652 & $<0.002$ & This study \\
\hline Stns $2,3,4,6,7,8$ & $Y=7.78+7.01 X$ & 71 & 0.740 & $<0.001$ & \\
\hline Stn 9 & $\mathrm{Y}=3.13+192.07 \mathrm{X}$ & 12 & 0.693 & $<0.01$ & \\
\hline $\operatorname{Stn} 10$ & $Y=4.43+11.03 X$ & 12 & 0.753 & $<0.005$ & \\
\hline Pooled data & $Y=10.02+1.99 X$ & 117 & 0.386 & $<0.001$ & \\
\hline (B) English Channel & & & & & Linley et al. 1983 \\
\hline $\operatorname{Stn}(F)$ & $Y=3.38+0.71 X$ & 9 & 0.936 & $<0.001$ & \\
\hline $\operatorname{Stn}(\mathrm{M})$ & $Y=3.03-0.32 X$ & 9 & -0.311 & $<0.5$ & \\
\hline Stn (E5) & $Y=9.40-3.37 X$ & 9 & -0.497 & $<0.2$ & \\
\hline Pooled data & $Y=2.87+0.74 X$ & 27 & 0.965 & $<0.001$ & \\
\hline Benguela Upwelling & $Y=0.79+1.05 X$ & 12 & 0.970 & $<0.001$ & \\
\hline Gulf of Mexico & $Y=5.19+0.72 X$ & 8 & 0.888 & $<0.002$ & \\
\hline $\begin{array}{l}\text { English Channel } \\
\text { Stn (A1) - pooled data }\end{array}$ & $\mathrm{Y}=2.31+0.44 \mathrm{X}$ & 28 & 0.790 & $<0.001$ & \\
\hline Celtic Sea & & & & & \\
\hline Stn (P34) & $\mathrm{Y}=2.81+0.68 \mathrm{X}$ & 9 & 0.914 & $<0.001$ & \\
\hline Benguela Upwelling & $Y=1.79+7.32 X$ & 28 & 0.320 & $<0.1$ & Painting et al. 1985 \\
\hline Stn 1 and 5 & $Y=8.39+2.68 X$ & 22 & 0.625 & $<0.001$ & This study \\
\hline Stns $2,3,4,6,7,8$ & $Y=10.04+9.48 X$ & 71 & 0.709 & $<0.001$ & \\
\hline $\operatorname{Stn} 9$ & $Y=3.57+228.00 X$ & 12 & 0.692 & $<0.01$ & \\
\hline $\operatorname{Stn} 10$ & $Y=5.43+16.76 X$ & 12 & 0.737 & $<0.005$ & \\
\hline (C) Freshwater literature & $\log \mathrm{Y}=5.91+0.76 \log \mathrm{X}$ & 20 & 0.948 & $<0.001$ & Bird \& Kalff 1984 \\
\hline Marine Literature & $\log Y=5.84+0.74 \log X$ & 19 & 0.888 & $<0.001$ & \\
\hline Overall literature & $\log Y=5.85+0.84 \log X$ & 40 & 0.948 & $<0.001$ & \\
\hline Stns 1 and 5 & $\log Y=6.07+0.31 \log X$ & 20 & 0.742 & $<0.001$ & This study \\
\hline Stns $2,3,4,6,7,8$ & $\log Y=6.31+0.31 \log X$ & 59 & 0.716 & $<0.001$ & \\
\hline Stn 9 & LoY $Y=6.71+0.42 \log X$ & 12 & 0.713 & $<0.01$ & \\
\hline Stn 10 & $\log Y=6.26+0.42 \log X$ & 12 & 0.760 & $<0.005$ & \\
\hline
\end{tabular}

the relative proportions of phytoplankton, bacterioplankton and microprotozoan consumers.

The linear relations between bacterial biomass and chlorophyll a provide an interesting point: the $Y$-intercept (Table 1; Fig. 5) shows that bacterial biomass was typically of the order 3 to $9 \mathrm{mg} \mathrm{C} \mathrm{m}^{-3}$ at zero chlorophyll a concentrations. In the absence of chlorophyll $a$, particulate organic carbon (POC) concentrations may nevertheless amount to 100 to $200 \mathrm{mg}$ $\mathrm{C} \mathrm{m}^{-3}$ even at $100 \mathrm{~m}$ depth and thus sustain bacterial growth (Lucas et al. 1986). Irrespective of chlorophyll a concentrations, bacterial biomass has indeed been found to closely correlate with total POC in the southern Benguela region (Lucas et al. 1986; $Y=0.060 X+$ 1.96, $r=0.77, n=85, p<0.001$ where $Y=$ bacterial biomass [ $\left.\mathrm{mg} \mathrm{C} \mathrm{m}{ }^{-3}\right]$ and $X=$ POC $\left.\left[\mathrm{mg} \mathrm{C} \mathrm{m}^{-3}\right]\right)$. South Atlantic Central Water thus appears to have a residual bacterial biomass of about $2 \mathrm{mg} \mathrm{C} \mathrm{m}^{-3}$, which survives under 'starvation-survival' conditions (Morita 1984) until advected into surface waters where it responds rapidly to conditions favorable for growth.

In order to make comparisons between the correlations found along the UML in March 1983 and those of other workers, we have re-expressed our data in terms of bacterial numbers (Table $1 \mathrm{~b}, \mathrm{c}$ ). Expressed as a linear function (Table $1 \mathrm{~b}$ ), the data for differing marine environments generally show broad agreement as expected, confirming the coupling of heterotrophic bacterial activity to primary production. Table $1 \mathrm{c}$ nevertheless shows that the relation between bacterial numbers and chlorophyll $a$ is better described as a power function (log-transformation of data) rather than as a linear function (see also Bird \& Kalff 1984). At high chlorophyll a concentrations and bacterial numbers $\left(>10^{6} \mathrm{mi}^{-1}\right)$, microflagellate and ciliate bacterivory generally maintains bacterial numbers and biomass at 


\section{a BACTERIAL BIOMASS $\left(\mathrm{mg} \mathrm{C}^{-3}\right)$}
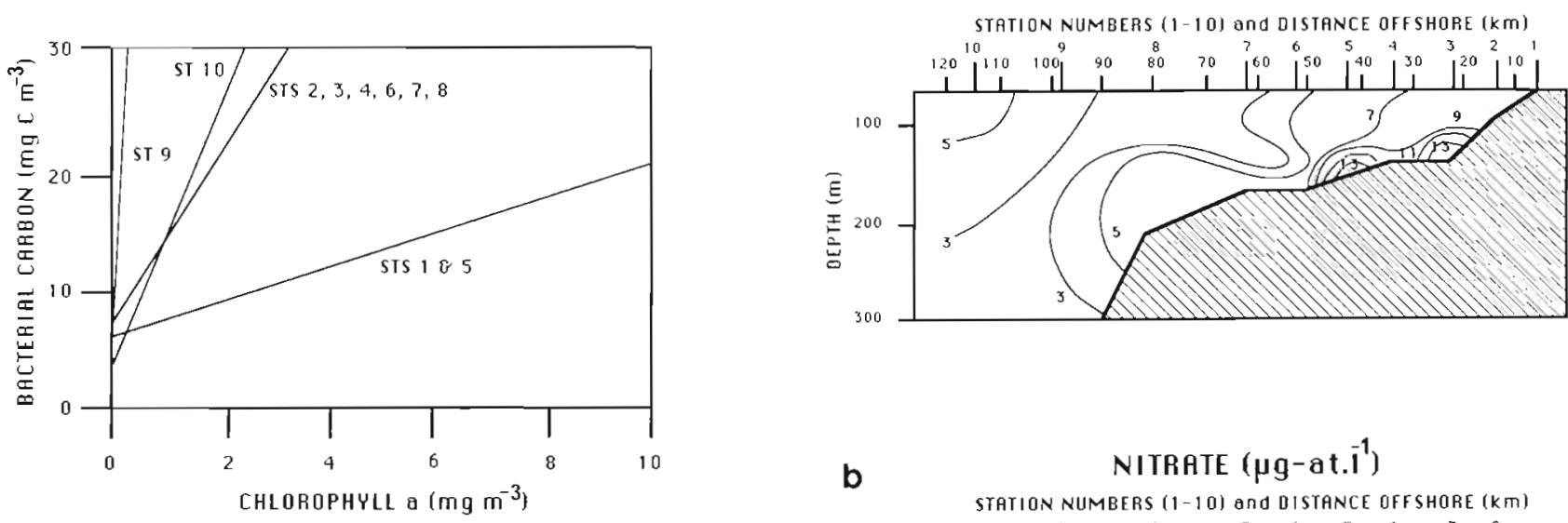

Fig. 5. Relation between bacterial biomass ( $\mathrm{mg} \mathrm{C} \mathrm{m} \mathrm{m}^{-3}$ ) and chlorophyll a $\left(\mathrm{mg} \mathrm{m}^{-3}\right)$ along the UML. Stns 1 and $5: Y=6.49$ $+1.41 X_{i} n=22, r=0.649, p<0.002$. Stns 2, 3, 4,6,7,8:Y= $7.78+7.01 X ; n=71, r=0.740, p<0.001$. Stn $9: Y=3.13+$ $192.07 X_{i} n=12, r=0.693, p<0.01$. Stn $10: Y=4.43+11.03 X_{i}$ $n=12, r=0.753, p<0.005$

levels lower than would be predicted from a linear function (Andersen \& Fenchel 1985, Verity 1985, Turley et al. 1986, Lucas et al. 1987). This mechanism is the most likely explanation for the observation that bacterial densities in the euphotic zone along the UML remained relatively constant between 2 and $5 \times 10^{6}$ cells $\mathrm{ml}^{-1}$.

\section{Nitrogen regeneration at the sediment-water inter- face}

Water overlying the shelf sediments along the UML transect showed elevated nitrate concentrations (23 to $26 \mu \mathrm{g}$-at $\mathrm{l}^{-1}$ ) with respect to South Atlantic Central Water (10 to $18 \mu \mathrm{g}$-at $\mathrm{l}^{-1}$; Chapman \& Shannon 1985) (Fig. 6). Associated with elevated nitrate concentrations were reduced oxygen concentrations (1.6 to $3.58 \mathrm{ml} \mathrm{l}^{-1}$ ) and elevated bacterial biomass (5.12 to $14.59 \mathrm{mg} \mathrm{C} \mathrm{m}{ }^{-3}$ ) relative to South Atlantic Central Water values for oxygen ( 4.8 to $5.2 \mathrm{ml} \mathrm{l}^{-1}$; Chapman \& Shannon 1985) and baterial biomass (ca 3 to $5 \mathrm{mg} \mathrm{C}$ $\mathrm{m}^{-3}$ in this study).

These data, particularly for the region between Stns 2 and 6 (15 to $50 \mathrm{~km}$ offshore) suggest localised nitrification at the sediment surface or in the immediately overlying waters. This is supported by a positive empirical relation between nitrate concentration $\left(Y, \mu g\right.$-at $l^{-1}$ ) and bacterial biomass $\left(X, \mathrm{mg} \mathrm{C} \mathrm{m}^{-3}\right)$ for waters immediately overlying the shelf sediments between Stns 2 and $6(Y=20.032+0.297 X, r=0.693, n=7$, $p<0.1)$. The expected depletion of oxygen $\left(Y, \mathrm{ml} \mathrm{l}^{-1}\right)$ by nitrification associated with the same bacterial biomass data is however only weakly apparent $(Y=$

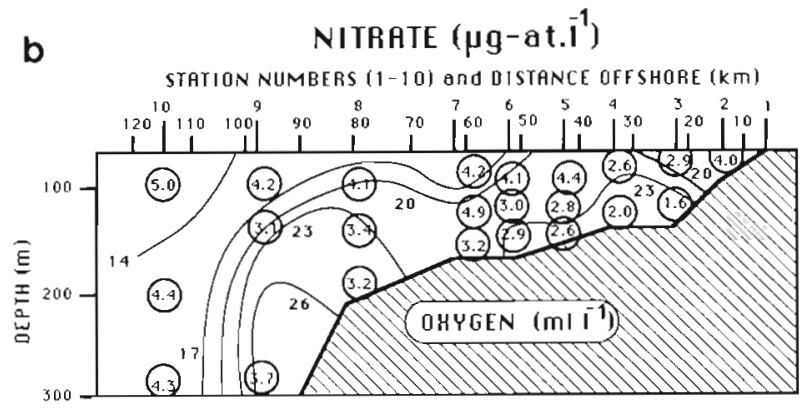

Fig. 6. Bacterial biomass and nitrate concentrations in the waters overlying the shelf sediments. (a) Bacterial biomass ( $\left.\mathrm{mg} \mathrm{C} \mathrm{m}{ }^{-3}\right)_{i}(b)$ nitrate concentrations ( $\mu \mathrm{g}$-at $\mathrm{l}^{-1}$ ), showing also oxygen concentrations ( $\mathrm{ml} \mathrm{l} \mathrm{l}^{-1}$ ) within circles

$3.881-0.117 X, r=0.483, n=7, p>0.1)$. Nevertheless, locally reduced oxygen concentrations over the shelf, termed 'oxygen-depleted' $\left(<5 \mathrm{ml} \mathrm{l}^{-1}\right.$ but $>2 \mathrm{ml}$ $\left.\mathrm{l}^{-1}\right)$ and 'oxygen-deficient' $\left(<2 \mathrm{ml} \mathrm{l^{-1 }}\right.$; Chapman \& Shannon 1985), occur commonly throughout the southern Benguela region. It has been suggested that the St Helena Bay region to the north may occasionally inject locally produced oxygen-depleted water into the peninsula region via an inshore south-flowing undercurrent which is prevalent during quiescent upwelling periods and NW winds (Andrews \& Hutchings 1980, Chapman \& Shannon 1985). Our earlier description of the hydrology along the UML at the time of the sampling does identify southward-flowing waters and NW winds so that the advection of low oxygen water southwards cannot be excluded. As oxygen conditions in waters overlying the sediments were apparently no lower than $1.6 \mathrm{ml} \mathrm{l}^{-1}$, nitrification rather than denitrification will prevail since nitrate reduction is inhibited by oxygen concentrations exceeding $0.15 \mathrm{ml} \mathrm{l}^{-1}$ (Chapman \& Shannon 1985). However, nitrification is dependent upon bacterial ammonification of organic nitrogen, originating primarily from phytoplankton sedimentation. For the St Helena Bay region, Bailey \& Chapman (1985) demonstrated that sedimentation and subsequent ammonification of the detritus can raise ambient $\mathrm{NH}_{4}^{+}-\mathrm{N}$ concentrations to as high as $8.4 \mu \mathrm{g}$-at $\mathrm{l}^{-1}$, although concentrations were generally between 
Table 2. $\mathrm{NH}_{*}^{+}-\mathrm{N}$ regeneration by microzooplankton $(<200 \mu \mathrm{m})$ relative to nitrogen requirements by phytoplankton in the southern Benguela upwelling region. Bacterial and phytoplankton data were obtained in December 1984 (Armstrong et al. 1987 ). SST = sea surface temperature; D $\%=$ depth of $1 \%$ light level. (\#) Probyn (1987): $\mathrm{R}=0.1528 \mathrm{~B}^{1.334}$, where $\mathrm{R}=$ regeneration by microplankton $(<200 \mu \mathrm{m}), \mu \mathrm{g}$-at $\mathrm{N}^{-1} \mathrm{~h}^{-1}, \mathrm{~B}=$ biomass of bacteria, $\mathrm{mg} \mathrm{I}^{-1} ; r=0.78, n=28, p<0.0001$

\begin{tabular}{|c|c|c|c|c|c|c|c|c|c|}
\hline \multirow[t]{2}{*}{ Station } & \multirow{2}{*}{$\begin{array}{c}\text { Water } \\
\text { type }\end{array}$} & \multirow{2}{*}{$\begin{array}{l}\text { SST } \\
\left({ }^{\circ} \mathrm{C}\right)\end{array}$} & \multirow{2}{*}{$\begin{array}{l}\mathrm{D} 1 \% \\
(\mathrm{~m})\end{array}$} & \multicolumn{2}{|c|}{ Phytoplankton production } & \multirow{2}{*}{$\begin{array}{l}\text { Bacterial } \\
\text { biomass } \\
m g \mathrm{C} \mathrm{m}^{-2}\end{array}$} & \multirow{2}{*}{$\begin{array}{l}\text { Microplankton } \\
\text { regeneration } \\
\mu g \text {-at } N 1^{-1} h^{-1} \\
\text { (\#) } \\
\text { (B) }\end{array}$} & \multirow{2}{*}{$\begin{array}{c}\mathrm{B} / \mathrm{A} \\
\%\end{array}$} & \multirow{2}{*}{$\begin{array}{c}\text { Mean } \\
\%\end{array}$} \\
\hline & & & & $\mathrm{mgC} \mathrm{m} \mathrm{Ch}^{-2}$ & $\begin{array}{c}\mu g \text {-at } N l^{-1} h^{-1} \\
\text { (A) }\end{array}$ & & & & \\
\hline $2-3$ & Inshore & 15.3 & 9 & 112.8 & 1.341 & 660.94 & 0.913 & 68.08 & 68.10 \\
\hline $4-4$ & Front & 16.3 & 16 & 80.9 & 0.963 & 294.47 & 0.256 & 26.64 & \\
\hline $3-3 A$ & Front & 16.2 & 19 & 258.9 & 3.079 & 183.66 & 0.128 & 4.16 & 15.30 \\
\hline $4-5$ & Front & 15.7 & 14 & 187.0 & 2.225 & 345.11 & 0.334 & $15.01)$ & \\
\hline $2-7$ & Oceanic & 18.1 & 33 & 65.4 & 0.778 & 687.64 & 0.631 & 81.09 & 6530 \\
\hline $4-10$ & Oceanic & 18.5 & 38 & 810 & 0.964 & 583.28 & 0.478 & 4958 & 65.30 \\
\hline
\end{tabular}

2 and $3 \mu \mathrm{g}$-at $\mathrm{l}^{-1}$. As chlorophyll a concentrations in surface waters of the UML were enhanced at the secondary inshore frontal feature $(45 \mathrm{~km}$ offshore; Figs $2 \mathrm{~b}$ and $3 \mathrm{a}$ ) which coincided with the position along the UML where bacterial populations at the sedimentwater interface were greatest and nitrate concentrations were elevated, we suggest that nitrogen cycling within the nearshore shelf-region may be closely coupled at certain times. High nitrate concentrations (up to $26 \mu \mathrm{g}$-at $\mathrm{l}^{-1}$ ) overlying the shelf edge $(80$ to $90 \mathrm{~km}$ IN RUHEffshore) may also originate from the inshore 'bottom' waters between Stns 2 and 6, since this water tends to slip back over the shelf-break edge when relaxation of SE winds occurs (Andrews \& Hutchings 1980).

\section{Nitrogen-regeneration in the watercolumn}

Recent studies have emphasized the importance of microheterotrophic activity as a source of regenerated nitrogen (Glibert 1982, Newell \& Linley 1984, Newell et al. 1985, Probyn \& Lucas 1987). In the upwelling region on the west coast of South Africa, Probyn (1987) showed that $\mathrm{NH}_{4}^{+}-\mathrm{N}$ regeneration by microplankton $(<$ $200 \mu \mathrm{m})$ was mostly confined to the upper water column and that $95 \%$ of total microplankton regeneration is attributable to the $<15 \mu \mathrm{m}$ size class, which includes bacteria and microflagellates. Similarly, for the Chesapeake Bay (USA) region, Glibert (1982) also noted that up to $87 \%$ of $\mathrm{NH}_{4}^{+}-\mathrm{N}$ remineralization occurred in the $<10 \mu \mathrm{m}$ size fraction and that the importance of the bacterial fraction $(<1 \mu \mathrm{m})$ may increase during the decline of phytoplankton blooms. By using the relation between bacterial biomass and nitrogen regeneration in the $<200 \mu \mathrm{m}$ size class (Probyn 1987), we have been able to estimate the potential for $\mathrm{N}$ regeneration by microplankton $(<200 \mu \mathrm{m})$ in the euphotic zone for this region. We have compared these values with phytoplankton $\mathrm{N}$-requirements calculated from the production rates obtained for inshore, frontal and offshore euphotic zones in the southern Benguela upwelling region. The data (Table 2) show that microplankton $\mathrm{NH}_{4}^{+}-\mathrm{N}$ regeneration at the inshore, frontal and oceanic stations could, on average, meet 68,15 and $65 \%$ respectively of phytoplankton nitrogen requirements at this time. For the inshore station, the considerable dependence of primary production on regenerated $\mathrm{NH}_{4}^{+}-\mathrm{N}$ is unexpected since Probyn (1985) has shown the f-ratio for these waters to be more typically 0.7 . However surface waters for the inshore region at this time show considerable evidence of sun-warming (15 $\left.{ }^{\circ} \mathrm{C}\right)$ relative to upwelled water $\left(10^{\circ} \mathrm{C}\right)$ indicating that this water has matured, allowing time for the development of an active microplanktonic community and hence high regeneration rates. The low dependence of primary production on regenerated nitrogen at the front (4 to $26 \%$ ) and high dependence in oceanic waters (50 to $81 \%$ ) confirms the views of Harnison (1980) and Holligan (1981) that well-stratified oceanic waters rely on epipelagically recycled nutrients while at the front physical mixing processes ensure that 'new' nitrogen can be entrained into the euphotic zone.

Acknowledgements. We are grateful to the officers and crew of RS 'Africana II' and especially to Miss S. J. Painting of the Sea Fisheries Research Institute for her aid in collecting some of the data. Our thanks are extended to Prof. G. Brundrit of the Oceanography Department, University of Cape Town, for many useful discussions on the significance of the CTD sections. Prof. J. G. Field of the Marine Biology Research Institute, UCT, offered comments on the manuscript which were much appreciated. Bacterial counts were performed by Mrs F. Verheye-Dua and Mr Ian Humphreys. Miss J. Burbidge provided assistance with the typing of the final. draft. The financial support of the Benguela Ecology Programme (SANCOR) is gratefully acknowledged. 


\section{LITERATURE CITED}

Andersen, P., Fenchel, T. (1985). Bacterivory by microheterotrophic flagellates in seawater samples. Limnol. Oceanogr. 30: $198-202$

Andrews, W R. H., Hutchings, L. (1980). Upwelling in the southern Benguela Current. Prog. Oceanogr. 9: 1-81

Armstrong, D. A., Mitchell-Innes, B. A., Verheye-Dua, F., Waldron, H., Hutchings, L. (1987). Physical and biological features across an upwelling front in the southern Benguela. In: Payne, A. I. L., Gulland, J. A., Brink, K. H. (eds.) The Benguela and comparable ecosystems. S. Afr. J. mar. Sci. 5: 171-190

Bailey, G. W., Chapman, P. (1985). The nutrient status of the St Helena Bay region in February 1979. In: Shannon, L. V. (ed.) South African ocean colour and upwelling experiment. Sea Fish. Res. Inst., Cape Town, p. 125-145

Barlow, R. G. (1982). Phytoplankton ecology in the southern Benguela Current. I. Biochemical composition. J. exp. mar. Biol. Ecol. 63: 209-227

Bird, D. F., Kalff, J. (1984). Empirical relationships between bacterial abundance and chlorophyll concentration in fresh and marine waters. Can. J. Fish. Aquat. Sci. 41: 1015-1023

Bjørnsen, P. K. (1986). Automatic determination of bacterioplankton biomass by means of image analysis. Appl. environ. Microbiol. 5: 1199-1204

Bratbak, G. (1985). Bacterial biovolume and biomass estimates. Appl. environ. Microbiol. 49: 1488-1493

Brundrit, G. B. (1986). The dynamic control of biological activity in the southern Benguela upwelling region. In: Nihoul, J. C. J. (ed.) Marine interfaces ecohydrodynamics. Elsevier, Amsterdam (Elsevier Oceanography Series 42): p. 95-104

Chapman, P., Shannon, L. V. (1985). The Benguela ecosystem. Part II. Chemistry and related processes. Oceanogr. mar Biol. A. Rev. 23: 183-251

Glibert, P. M. (1982). Regional studies of daily, seasonal and size fraction variability in ammonium remineralization. Mar. Biol. 70: 209-222

Harrison, W. G. (1980). Nutrient regeneration and primary productivity in the sea. In: Falkowski, P. G. (ed.) Primary productivity of the sea. Plenum Press, New York: 433-460

Hobbie, J. E., Daley, R. J., Jasper, S. (1977). Use of nuclepore filters for counting bacteria by fluorescence microscopy. Appl. environ. Microbiol. 33: 1225-1228

Holligan, P. M. (1981). Biological implications of fronts on the northwest european Shelf. Phil. Trans. R. Soc. A. 302: $547-562$

Hutchings, L., Armstrong, D. A., Mitchell-Innes, B. A. (1985). The frontal zone in the southern Benguela Current. In: Nihoul, J. C. J. (ed.) Marine interfaces ecohydrodynamics. Elsevier, Amsterdam (Elsevier Oceanography Series 42), p. $67-94$

Hutchings, L., Holden, C., Mitchell-Innes, B. A. (1984). Hydrological and biological shipboard monitoring of upwelling off the Cape Peninsula. S. Afr. J. Sci. 80: 83-89

Lancelot, C., Billen, G. (1984). Activity of heterotrophic bacteria and its coupling to primary production during the spring phytoplankton bloom in the southern bight of the North Sea. Limnol. Oceanogr. 29: 721-730

Le Fèvre, J. (1986). Aspects of the biology of frontal systems. Adv mar. Biol. 23: 163-299

Linley, E. A. S., Newell, R. C., Lucas, M. I. (1983). Quantitative relationships between phytoplankton, bacteria and heterotrophic microflagellates in shelf waters. Mar. Ecol. Prog. Ser 12: 77-89
Lucas, M. I., Painting, S. J., Muir, D. G. (1986). Estimates of carbon flow through bacterioplankton in the s. Benguela upwelling region based on ${ }^{3} \mathrm{H}$-Thymidine incorporation and predator-free incubations. GERBAM-Second International Colloquium of Marine Bacteriology, CNRS, Brest, October 1984. IFREMER, Actes de Coll. 3: 375-383

Lucas, M. I., Probyn, T A., Painting, S. J. (1987). An experimental study of microflagellate bacterivory: further evidence for the importance and complexity of microplanktonic interactions. In: Payne, A. I. L., Gulland, J. A., Brink, $\mathrm{K}$. H. (eds.) The Benguela and comparable ecosystems. S. Afr. J. mar. Sci. 5: 791-808

Morita, R, Y (1984). Substrate capture by marine heterotrophic bacteria in low nutrient waters. In: Hobbie, J. E., Williams, P. J. LeB. (eds.) Heterotrophic activity in the sea. Plenum Publ. Corp, New York, p. 83-100

Mostert, S. A. (1983). Procedures used in South Africa for the automatic photometric determination of micronutrients in seawater. S. Afr. J. mar. Sci. 1: 189-198

Nelson, G. (1985). Notes on the physical oceanography of the Cape Peninsula Upwelling System. In: Shannon, L. V. (ed.) South African ocean colour and upwelling experiment. Sea Fish. Res. Inst. Cape Town: p. 63-95

Newell, R. C., Linley, E. A. S. (1984). Significance of microheterotrophs in the decomposition of phytoplankton: estimates of carbon and nitrogen flow based on the biomass of plankton communities. Mar. Ecol. Prog. Ser. 16: 105-119

Newell, R. C., Lucas, M. I., Painting, S. J., Field, J. G. (1985). Some estimates of carbon and nitrogen flux through pelagic communities in coastal waters. In: Gibbs, P. E. (ed.) Proceedings 19th European Marine Biology Symposium. Cambridge Univ. Press, Cambridge, p. 51-59

Newell, R. C., Turley, C. M. (1987). Carbon and nitrogen flow through pelagic microheterotrophic communities. In: Payne, A. I. L., Gulland, J. A., Brink, K. H. (eds.) The Benguela and comparable ecosystems. S. Afr. J. mar Sci. 5; $717-734$

Painting, S. J., Lucas, M. I., Stenton-Dozey, J. M. E. (1985). The South African SIBEX I cruise to the Prydz Bay region, 1984: 10. Biomass and production of bacterioplankton in Prydz Bay, Antarctica, and phytoplankton, detritus and bacterial relationships. S. Afr. J. antarct. Res. 15: 42-52

Probyn, T A. (1985). Nitrogen uptake by size-fractionated phytoplankton populations in the southern Benguela upwelling system. Mar. Ecol. Prog. Ser. 22: 249-258

Probyn, T. A. (1987). Ammonium regeneration by microplankton in an upwelling environment. Mar. Ecol. Prog. Ser. 37 : $53-64$

Probyn, T. A., Lucas, M. I. (1987). Ammonium and phosphorus flux through the microplankton community in Agulhas Bank waters. In: Payne, A. I. L., Gulland, J. A., Brink, K. H. (eds.) The Benguela and comparable ecosystems. S. Afr. J. mar. Sci. 5: 209-221

SCOR/UNESCO Working Group 17 (1966). Determination of photosynthetic pigments. In: Determination of photosynthetic pigments in seawater. UNESCO, Paris, Monographs on Oceanographic Methodology 1: 9-18

Shannon, L. V., Walters, N. M., Mostert, S. A. (1985). Satellite and near-surface chlorophyll in the southern Benguela region. In: Shannon, L. V. (ed.) South African ocean colour and upwelling experiment. Sea Fish. Res. Inst. Cape Town, p. $183-210$

Sherr, B. F., Sherr, E. B., Andrew, T. L., Fallon, R. D., Newell, S. Y (1986). Trophic interactions between heterotrophic protozoa and bacterioplankton in estuarine water analyzed with selective metabolic inhibitors. Mar. Ecol. Prog. Ser. 32: 169-179 
Turley, C. M., Newell, R. C., Robinson, D. B. (1986). Survival strategies of two small marine ciliates and their role in regulating bacterial community structure under experimental conditions. Mar. Ecol. Prog. Ser 33: 59-70

Verity, P. G. (1985). Grazing, respiration, excretion and growth rates of tintinnids. Limnol. Oceanogr. 30 : $1268-1282$

Waldron., H. N. (1985). Influences on the hydrology of the Cape Columbine/St Helena Bay region. M. Sc. thesis, Oceanography Department, University of Cape Town

This article was submitted to the editor; it was accepted for printing on June 9, 1988 